\title{
EXPERIMANTAL INVESTIGATIONS INTO GAS FLOW IN PLANE MODEL OF ROTARY DETONATION ROCKET ENGINE
}

Institute of Technical Mechanics of the National Academy of Sciences of Ukraine and the State Space Agency of Ukraine, 15, Leshko-Popel Str., Dnepr,Ukraine, 49005, e-mail: gl_konstruktor@ukr.net

The problem of a low specific pulse of the rotary detonation rocket engine described in the related literature is examined. The research objective is to reveal the factors degrading the characteristics of the systems of this type. It is assumed that due to the structure of propellant components flow in the zone of their mixing only the portion detonates, and the rest reacts in the deflagration mode. To confirm the assumption under consideration, the experimental investigations have been conducted. The test results are obtained using a plane model of the rotary detonation rocket engine. The experimental test installation and the testing technique are described. The patterns of isolines for static and total pressures, as well as the flow patterns are presented. From this information, it can conclude that the flow is supersonic with complex vortices and shock waves. Although while interacting with these flow elements the detonation wave propagates, but in so doing loses a share of energy, affecting the specific pulse.

Keymords rotary detonation rocket engine, detonation wave, flow pattern, injector, total and static pressures, visualization, black-oil coating.

1. Ivanov V. K., Kashkarov A. M., Romasenko Ye. N., Tolstikov L. A. Turbo-pump assemblies for liquid rocket engine developed by NPO Energomash. Konversia v Mashinostroenii. 2006. No 1. P. $1-6$.

2. Bykovsky F. A., Zhdan S. A. Continuous Spin Detonation. Novosibirsk: Publishing House of Siberian Branch of RAS. 2013. 423 p.

3. Pulse Detonation Engines. Edited by S. M. Frolov. M.: TORUS PRESS. 2006. 592 p.

4. Shank Jason C. Development and Testing of a Rotating Detonation Engine Run on Hydrogen and Air: Thesis presented to the Faculty Department of Aeronautics and Astronautics, Graduate School of Engineering and Management, Air Force Institute of Technology, Air University, Air Education and Training Command in partial fulfillment of the requirements for the Degree of Master of Science in Aeronautical Engineering. USAF. 2012. 70 p.

5. Russo Rachel M. Operational Characteristics of a Rotating Detonation Engine using Hydrogen and Air: Thesis presented to the Faculty Department of Aeronautics and Astronautics, Graduate School of Engineering and Management, Air Force Institute of Technology, Air University, Air Education and Training Command in Partial Fulfillment of the Requirements for the Degree of Master of Science in Aeronautical Engineering. USAF. 2011. 90 p.

6. James A. Suchocki Operational Space and Characterization of a Rotating Detonation Engine Using Hydrogen and Air: Thesis presented in partial fulfillment of the requirements for the Degree Master of Science in the Graduate School of the Ohio State University. The Ohio State University. 2012. 116 p.

7. Chaplits A. D., Astapov A. I. Visualization of Gas Flows through Inner Channels. Dniepropetrovsk: ITM, NASU\&NSAU. 2003. 412 p.

8. Netleton M. Detonation through Gases. Translated from English. Edited by L. G. Gvozdeva. M.: Mir. 1989. $280 \mathrm{p}$.

9. Petunin A. N. Methods and Technique for Measuring Gas Flow Parameters. M.: Mashinostroenie. 1972. 332 p.

10. Deych M. Ye. Engineering Gas Dynamics. Second edition revised. M.: Gosenergoizdat. 1961. 671 p. 